\title{
米と小麦タンパク質の栄養価の比較
}

\author{
村田希久，山本公子，池田喜美子，田中淑子 \\ 大阪市立大学家政学部食物学科
}

\section{Comparison Between Nutritional Value of Rice and Wheat Proteins}

\author{
Kiku Murata, Kimiko Yamamoto, Kimiko Ikeda, Yoshiko Tanaka \\ Food and Nutrition Laboratory, Faculty of the Science of Living \\ Osaka City University, Sumiyoshi-ku, Osaka \\ J. Jap. Soc. Food and Nutr., 24 (6), 355 360 (1971)
}

The nutritional value of the rice protein was compared with that of the wheat protein at three different protein levels by the rat feeding experiment.

The diets were prepared from the protein concentrated rice $(26.9-33.6 \%$ in protein) treated with $\alpha$-amylase, the wheat gluten ( $69.4 \%$ in protein), wheat starch, rice powder, and wheat flour etc.

The results obtained were as follows:

1) Protein efficiency ratio (PER) of the rice protein at $11 \%$ protein level was 1.67 (mean), while that of the wheat protein was 0.79 (mean). The ratio was the rice protein 100 : the wheat protein 47 (100: 79 in literature).

2) Biological value (BV) of the rice protein at $11 \%$ protein level was 63.1 , while that of the wheat protein was 49.1 ; in the ratio of each value was $100: 68$ (100:89 in literature).

3) Linear correlations betwen the nitrogen intake and the body weight gain in the both rice and wheat groups were observed. The slope of the regression line in the rice diet and the wheat diet was $10.24 \mathrm{~g} /$ $\mathrm{Ng}$ intake and $6.74 \mathrm{~g} / \mathrm{Ng}$ respectively; in the ratio was $100: 66$.

These results indicate that difference between the nutritional value of the rice and wheat proteins are greater than those have been mentioned previously.

(Received July 8, 1971)

精白米のタンパク質は精白小麦のタンパク質よりも一 般に含量は低いか，前者の窒素当りの各必須了ミノ酸量 はいずれも後者のそれよりも幾分高く，幼白ネズミの生 長にお上は方效果中生物価 (Biological Value, BV) 。 高いことは既知の事実とされている。

しかし両タンパク質の栄歪価を同一レベルにおいて同 時に比較した結果をみない。著者らは別報で述べる米や 小麦タンパク質へのリジン，スレオニン補足効果を再椎 討するに先立って，まず米，小麦両タンパク質の栄養価 を同一条件で比較することを企てた。

タンパク質の栄盖価の判定法としてこれまで数多くの 方法が提出されているが，今回はタンパク質10\%程度の 飼料を幼白ネズミに自由食で投与して求めたタンパク質 効新比 (Protein Efficiency Ratio, PER) とBV のほか Hegsted') らの方法に準じ米と小麦について各タンパク 質レベルの飼料を自由食とし，摂取窒素と体重增量の相
関と，各值線の仳斜を求め，これらを比校する方法など をも採用して雨タンパク質の質を比較した。

実験には米ならびにこれをい-アミラーゼ処理したタ ンパク質澧縮米粉を用いて調製した種々のタンパクレベ ルの米群と,小麦粉ならびに小麦タンパク質として敞婪, （予備実虽に扣いてて使用）もしくは生猌粉末を用いて調裂 した種々のタンパクレベルの小麦群につき, 幼白ネズミ による生長実験を 3 回行なった。その結果米タンパク質 のPERや BVは小麦タンパク質のそれらよりもかなり高 く, 従来の文献値よりも両者に大きな開きのあることが 認められた。以下実験方法と結果などについて述べる。

\section{実 験方 法}

\section{1. 空素の測定とタンパク質係数}

尿ならびに䔬の窒菜はヶルダール法によった。米，小 麦その他飼料用材料の窒素もケルダール法により, 米タ 
ンパク質，小麦タンパク質の算出にはそれぞれ系数5. 95 と 5.70 を採用した。

\section{2. 実験材料}

1）米タンパク質の濃縮 大弥食品より分譲を受け た（昭和 42 年石川県産の硬質粳米を高速粉呼機にて粉 碎した)米粉を用い, Fig. 1に示寸方法によってタンパ ク質洪縮米粉を調慜した。実験に用いた細菌 $\alpha$ ーアミラ 一ゼは生化学工業より購入の（1 部上田化学より直接 分譲を受けた)純 $\alpha$-アミラーゼ (Amylo·1·4·dextrinase) の結晶, $662 \mathrm{U} / \mathrm{mg}$ の protease-free の標品である。米 と $\alpha$-アミラーゼの量的関係については前以って種々予

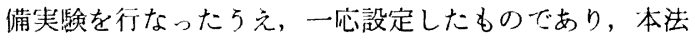
により調慗したタンパク質淑縮米粉のタンパク質含量は 20. 9〜33.6\%である。

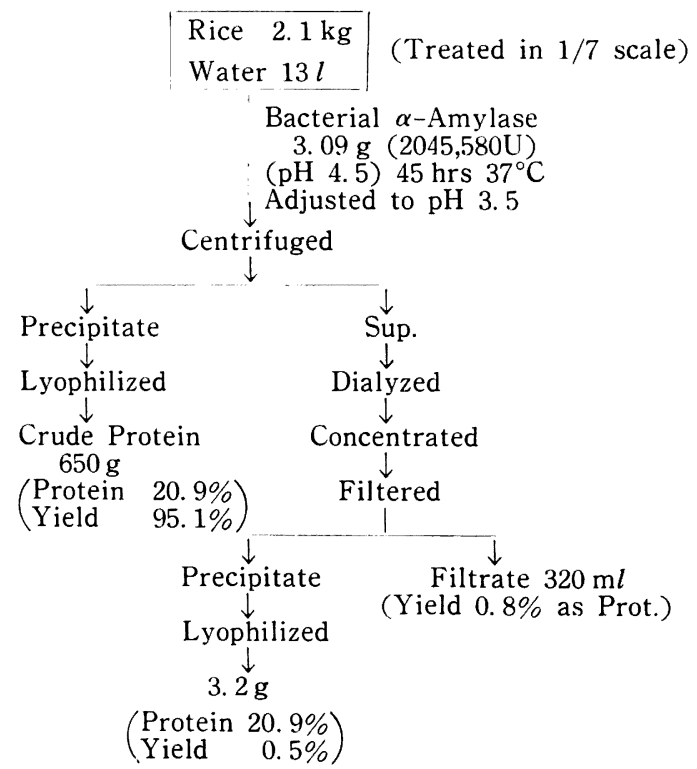

Fig. 1. Preparation of the rice protein concentrate

2）小麦ダルテン 予倩実験に用いた焼麩は市販品の 粉末，本実験で用いた小麦グルテンは新進食料工業より 分譲を受けたものでタンパク質含量 $69.4 \%$ ものである

\section{3. 飼料の調製}

予備実験では米，小麦群それぞれタンパク質レベル4 $\%, 6 \%, 11 \%$ の飼料を調製するため Table 1に示すよ5 にタンパク質濃縮米粉もしくは数粉とでん粉を混合し， それぞれタンパク質レベル 4.5\%,6.8\%,13.6\%のもの を調製しこれれを $88.9 \%$, 油 $5 \%$, 塩混合 $4 \%$,ビタミ ン混合 $2 \%$ とコリン塩酸塩のアルコール溶液 $0.1 \mathrm{~m} l$ を 混和し,さらにチョコラ $0.05 \mathrm{ml} / 100 \mathrm{~g}$ 飼料を添加して 飼料を調製した。本実験では Table 2 に示すように米, 小麦それぞれタンパク質レベル5.5\%,11.0\%，19\%の飼 料を調製した。
Table 1. Preparation of rice or wheat diets

\begin{tabular}{lcccccc}
\hline \hline Protein level \% & 4.5 & 6.8 & 13.6 & 4.5 & 6.8 & 13.6 \\
Rice g & 659 & 1000 & 589 & - & - & - \\
Rice prot. conc.* g & - & - & 481 & - & - & - \\
$\alpha$-Corn starch g & 341 & - & - & 827 & 737 & 475 \\
Gluten(dried)** g & - & - & - & 173 & 263 & 525 \\
\hline \hline
\end{tabular}

*Protein $20.9 \% \quad * *$ Protein $25.9 \%$

Table 2. Diet composition

$(\%)$

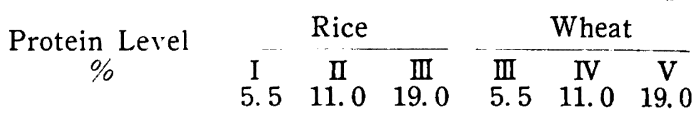

$\begin{array}{lllllll}\text { Rice or Wheat } & 88.9 & 72.1 & 42.9 & 39.7 & 79.4 & 76.9\end{array}$ Starch

Conc. Rice* or Gluten**

- $\quad-\quad 49.29 .5-$

Corn oil

$-16.846 .0-\quad-12.0$

Salt mix.

$\begin{array}{llllll}5 & 5 & 5 & 5 & 5 & 5\end{array}$

Vit. mix.

$\begin{array}{llllll}4 & 4 & 4 & 4 & 4 & 4\end{array}$

Choline

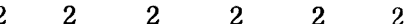

$\begin{array}{llllll}0.1 & 0.1 & 0.1 & 0.1 & 0.1 & 0.1\end{array}$

* Protein 33.6\% ** Protein 69.4\%

Chocola A $0.05 \mathrm{ml} / 100 \mathrm{~g}$ diet were added containing V.A 1,500 I. U. V.E 150 I. U.

\section{4. 飼育動物と飼育方法}

Donryu 系白ネズミ雄, 体重 $50 \mathrm{~g}$ 前後のすのを日本 動物より購入し 3〜4 日20\%カゼイン食で条件をととの えた後, 各群 $7 \sim 8$ 匹に群別し, 平均体重 $70 \mathrm{~g}$ から試験 食を自由食で与えた。毎日もしくは隔日に体重と飼料摂 取量を測定し, 室温 $23 \sim 24^{\circ} \mathrm{C}$ に20日間飼育した。

\section{5. 生物価とタンパク質効率比の测定}

予備実験では小麦（猌）のタンパク質レベル6\%群へ 米との差に相当するリジンとスレオニン補足実験をす加 えた関係上，6\%群について10〜12日と18〜20日の 2 日 尿と䔬を 2 回採取してそれらの窒素を測定した。一方本 実験ではタンパク質 $11 \%$ の米と小麦群について13〜15日 と 18〜20 日目の 2 日尿と䔬を 2 回採取して窒索を測定 し, 別に無タンパク質群の尿ならびに䔬の窒素を差引き 生物価を算出した。またタンパク質効率比は予備実駼, 本実験ともにタンパク質 $11 \%$ 群について20日間の摄取飼 料量より求めたタンパク質摂取量と体重增加量より算出 した。

\section{実 験 結 果}

\section{1. タンパク質浱樎米粉}

予備実験に用いた濃縮米は遠心管である程度上清を分 別した跨状のものを凍結乾燥したため，タンパク質濩度 は20\%程度で，上清からもさらに，透析によって糖を除 
いたものからタンパク質部分を得た。全収量は計算值の 96. 4\%であった。本実験でさらに多量の米について1 回 $300 \mathrm{~g}$ の米に $\alpha$-アミラーゼ $0.22 \mathrm{~g}(144,000 \mathrm{U})$, 前回 の半量を用いて実験したが，液化状態はよく，また連続 遠心によりタンパク質部分を分離して凍結乾燥したため タンパク質 $33.6 \%$ ，収量 $94.8 \%$ で，汇夜に約 $2 \%$ に相 当するタンパク質部分が失われた程度であった。得たタ ンパク質濃縮米粉と效の粉末とのアミ/酸組成について 田辺研究所の御好意により，分析していただいた結果 はTable 3 に示すようで, 米や猌のアミノ酸値の文献値 に比しフェニルアラニン含量が高いほか, 各アミノ酸値 とも大差なく，米のタンパク質浱縮によって，タンパク 質は分画されておらず，米タンバク質栄養価の実験に使 用する試料として満足すべきものであると考えられた。

Table 3. Amino acid composition of rice, fu and wheat $(\mathrm{g} / \mathrm{Ng})$

\begin{tabular}{llllll}
\hline \hline & \multicolumn{2}{c}{ Rice } & \multicolumn{2}{c}{ Fu } & Wheat \\
& A* & \multicolumn{1}{c}{ L } & \multicolumn{1}{c}{ A } & L \\
\hline Ileu & 0.27 & 0.28 & 0.24 & 0.26 & 0.24 \\
Leu & 0.52 & 0.52 & 0.46 & 0.45 & 0.44 \\
Lys & 0.20 & 0.21 & 0.10 & 0.11 & 0.13 \\
Met & 0.18 & 0.14 & 0.10 & 0.11 & 0.09 \\
Cys & 0.15 & 0.13 & 0.13 & 0.12 & 0.12 \\
Phe & 0.34 & 0.29 & 0.34 & 0.29 & 0.29 \\
Tyr & 0.28 & 0.38 & 0.20 & 0.18 & 0.19 \\
Thr & 0.22 & 0.22 & 0.16 & 0.17 & 0.16 \\
Try & 0.053 & 0.080 & 0.047 & 0.060 & 0.070 \\
Val & 0.38 & 0.37 & 0.26 & 0.28 & 0.28 \\
Arg & 0.51 & 0.36 & 0.21 & 0.18 & 0.23 \\
His & 0.16 & 0.14 & 0.15 & 0.10 & 0.11 \\
Ala & 0.34 & 0.37 & 0.17 & 0.13 & 0.15 \\
Asp & 0.59 & 0.67 & 0.22 & 0.19 & 0.25 \\
Glu & 1.2 & 1.1 & 2.4 & 2.1 & 2.0 \\
Gly & 0.29 & 0.27 & 0.23 & 0.20 & 0.20 \\
Pro & 0.31 & 0.32 & 0.90 & 0.80 & 0.80 \\
Ser & 0.32 & 0.23 & 0.29 & 0.30 & 0.30 \\
\hline \hline
\end{tabular}

* Rice protein concentrate

A ...Analytical data, L ... Data cited from The Amino Acid Composition of Food in Japan 1966

なお米タンパク質濃縮のための $\alpha$-アミラーゼ使用量 山本条件で米 $1 \mathrm{~kg}$ 当り $0.73 \mathrm{~g}(480,000 \mathrm{U}$ ) (Fig. 1 に示 した量の半量）ではほ充分であった。

\section{2. 飼料摄取量ट体重增量}

*もしくは麩タンパク質各レベルの飼料で飼育した予 偖実験に批ける各群の飼料摂取量と体重增の平均は Fig. 2に示すよ5で，枎に由来するタンパク質 $11 \%$ の体重增 は米タンパク質 $4 \%$ 群と同程度にすぎなかった。本実験 におけるタンパク質 $5.5 \%, 11 \% ， 19 \%$ 米もしくは小

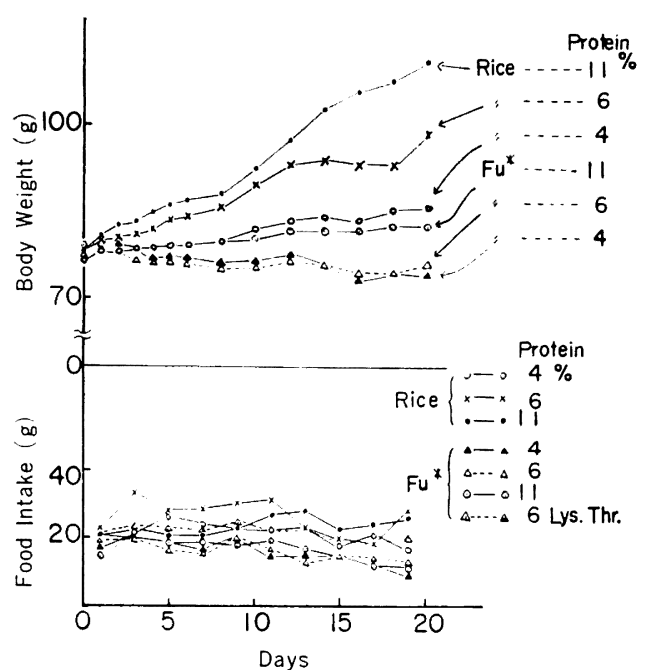

Fig. 2. Changes in body weight and fcod intake.

* Baked gluten
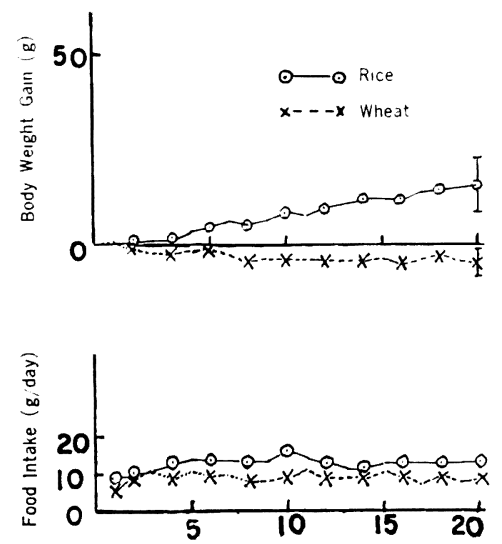

Days

Fig. 3. Body weight gain and food intake(5.5\% prot.).
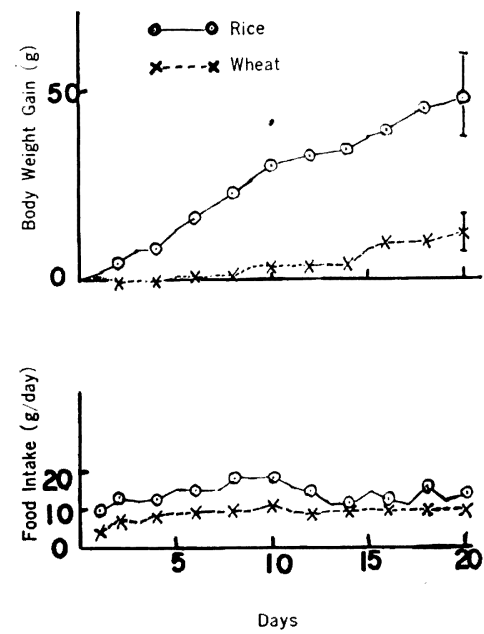

Fig. 4. Body weight gain and food intake(11\% prot.). 

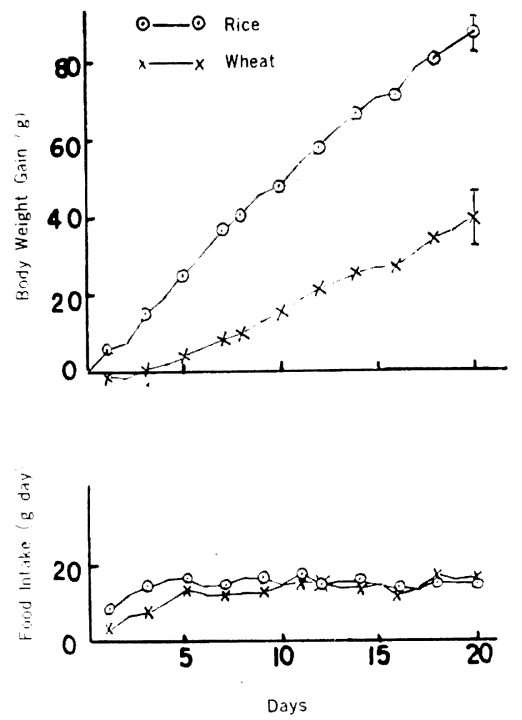

Fig. 5. Body weight changes and food intake (19\% prot.).

麦グルテンの飼料揸取量と体重增はそれぞれ Fig. 3， Fig. 4, Fig. 5 に示すよ5で各タンパク質レベルにおい て小麦タンパク質群の体重增量は米タンパク質群のそれ よりも著しく劣ることが観察された。

3. 米ならひに小麦タンパク質のタンパク質効率比 (PER)

前項で示した予備奏験の5ちタンパク質レベル11\%群 における米, 猌群20日間の飼料摂取量より求めた摂取夕 ンパク質量と，体重增量より求めた PER は米において 2. $59 \pm 0.15^{*}$ 麩において $0.44 \pm 0.10 *$ であった。また， 本実㩆のタンパク質11\%。群で求めた結果は Table 4 に 示すようである。本表に抽ける Expt. No. 2のデーター は, 次嘏の米もしくは小麦タンパク質へのリジン，スレ オニン補足効果の実験における非添加群について求めた ものであるが，いずれも文献值よりも小麦タンパク質の

Table 4. Protein Efficiency Ratio of rice or wheat protein

\begin{tabular}{ccc}
\hline Expt. No. & Rice & Wheat \\
\hline 1 & $\begin{array}{c}1.60 \pm 0.14 \\
(100)\end{array}$ & $\begin{array}{c}0.62 \pm 0.10 \\
(39)\end{array}$ \\
2 & $\begin{array}{c}1.75 \pm 0.03 \\
(100)\end{array}$ & $\begin{array}{c}0.96 \pm 0.05 \\
(54)\end{array}$ \\
Mean & $1.67(100)$ & 0.79 \\
Literature* & $1.9(100)$ & $1.5(77)$ \\
& 9 & $(79)$ \\
\hline \hline
\end{tabular}

* A. M. Altschul: "Protein"

( ) $\cdots$ Ratio \pm S. E.

$* \pm \mathrm{S} . \mathrm{E}$.
PER が著しく低く米の PER 值を100とした時の Ratio は文献値の79に対し,47とかなり低いことが観察された。

4. 米ならひに小麦タンパク質の生物価 (Biological Value, BV)

予倩実験のタンパク質レペル $6 \%$ 群について摄取重量か ら䔬中窒素を差引いた吸収窒素量 $\mathrm{A} に$ 対する尿中窒素量 から算出した保留窒素A-Bの割合を求めた結果はTable 5 に示すよ5で, 米のB V2 回平均値 61.4に対し橉では 34.6でその比は米 100 : 妋50であった。なお本実験の結 果は Table 6 に示すよ5で，米タンパク質のBV63.1に 対し小麦タンパク質では49.1でその比は米100: 小麦 78 で, 予侕，本実験共文献值における米 100 ：小麦 89より も小麦においてかなり低い結果であった。

Table 5. Biological Value of rice or wheat

\begin{tabular}{|c|c|c|c|c|}
\hline \multirow[b]{2}{*}{ Period* } & \multicolumn{2}{|c|}{ Rice } & \multicolumn{2}{|c|}{ Wheat } \\
\hline & 1 & 2 & 1 & 2 \\
\hline $\begin{array}{l}\mathrm{N} \text { Absorbed** } \\
\mathrm{mg}(\mathrm{A})\end{array}$ & 300 上15 & 268 上 6 & 174 上 15 & $139 \pm 26$ \\
\hline $\begin{array}{l}\text { Urinary } \mathrm{N}^{* *} \\
\mathrm{mg}(\mathrm{B})\end{array}$ & $115 \pm 7$ & $100 \pm 4$ & $110 \pm 11$ & $94 \pm 22$ \\
\hline (A) $-(\mathrm{B}) \times 100 \%$ & 60.1 & 62.7 & 36.8 & 32.4 \\
\hline & $\begin{array}{r}61 \\
(10\end{array}$ & & & \\
\hline
\end{tabular}

* Period $1 \cdots 10 \sim 12$ th day; $2 \cdots 18 \sim 20$ th day \pm S.E. ** Appearance

( ) $\cdots$ Ratio

Table 6. Biological Value of rice or wheat protein (11\% protein level)

\begin{tabular}{lcccc}
\hline \hline & \multicolumn{2}{c}{ Rice } & \multicolumn{2}{c}{ Wheat } \\
\hline Period* & 1 & 2 & 1 & 2 \\
$\begin{array}{c}\text { N Absorbed** } \\
\text { mg(A) }\end{array}$ & $431 \pm 54$ & $437 \pm 52$ & $300 \pm 47$ & $308 \pm 23$ \\
$\begin{array}{c}\text { Urinary N** } \\
\text { mg(B) }\end{array}$ & $158 \pm 21$ & $149 \pm 18$ & $138 \pm 30$ & $160 \pm 18$
\end{tabular}
$\frac{(\mathrm{A})-(\mathrm{B})}{(\mathrm{A})} \times 100 \% 63 . \underbrace{3 \quad 62.9}_{63.1}$
$54 . \underbrace{2 \quad 44} 4.0$
49.1 (78)
Literature
75.0 (100)
67 (89)

* Period $1 \cdots 15 \sim 17$ th day; $2 \cdots 22 \sim 24$ th day \pm S. E. **Metabolic nitrogen was subtracted.

( )...Ratio

\section{5. 窒素恸取量と体重増量の相関}

予備実験における米ならびに麩タンパク質各レベル各 々 3 群について窒素摂取量と体重增量の平均値をプロッ

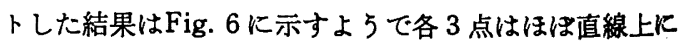
あった。本実験に批いて米，小麦各群 1 匹ずつについて プロットした結果は Fig. 7にすよ5で捸取窒素量と体重 增量の相関係数は米において0.97，麦において0.95であ 


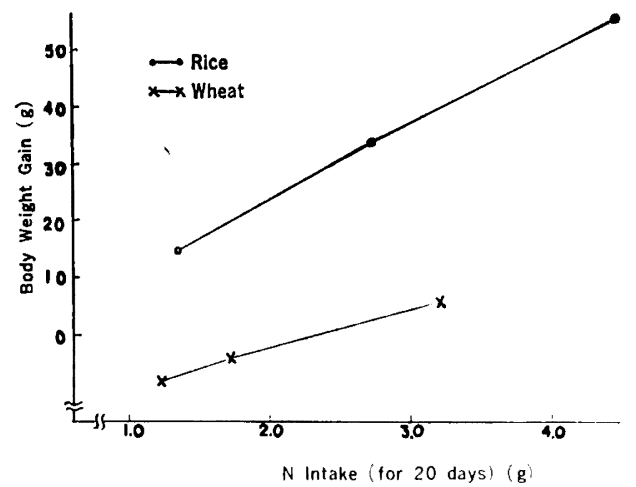

Fig. 6. The relationship between gain in weight and $\mathrm{N}$ intake

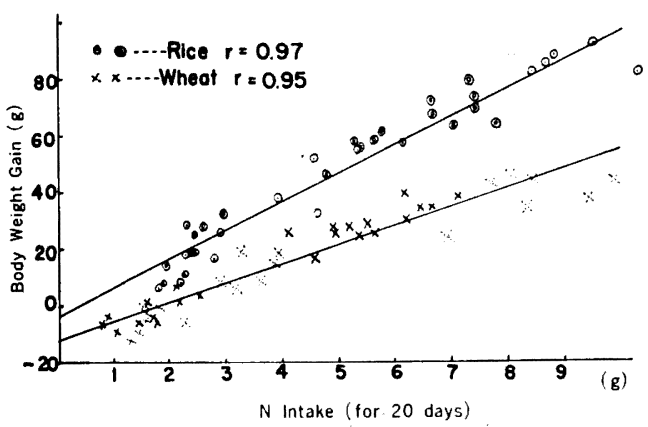

Fig. 7. Relationship between gain in weight and $\mathrm{N}$ intake from diet of rice or wheat.

った。また体重增の傾斜の傾きは米 $10.24 \mathrm{~g} / \mathrm{Ng}$, 麦 6.74 $\mathrm{g} / \mathrm{Ng}$ でその比は $100: 66$ であった。

\section{考察}

食品タンパク質の栄養価を判定する時は普通食品その るのを他の成分と配合して飼料を調製するためタンパク 質レペルはその食品のタンパク質含量よりも低い点で実 䀦することになる。しかし一般にタンパク質含量の高い 食品のタンパク質の栄養価が求められているので食品タ ソパク質の PER は従来10\%レペルで比較することが望 ましいとされている。

しかし各食品のタンパク質は質によって最高の体重增 をきたすタンパク質レベルもしくは摄取窒素量は異な る。この点を考虑し Hegsted"1 を比較するに当り各食品につき種々のレベルのタンパク 質含量の飼料を調製してこれらで幼白ネズミを飼有し摂 取N当りの体增量の傾斜から牛乳フルブミン,カゼイン, 大豆タンパク質，小麦タンパク質の比較を行なった。し かし米タンパク質について各タンパク質レベルでの実験 を行なっていない。

米のタンパク質はでん粉顆粒中に protein body とし て分散しており，小麦 gluten のよ5に容易に水洗によ
ってでん粉粒子を除くことが困難であるため，米タンパ ク質の濃維は極めて手数を要する。そのため米タンパク 質につき高レペルでその栄養価を他のタンパク質と比較

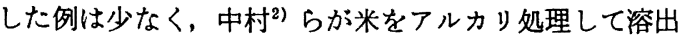
させた米タンパク質を酸性沈澱により約 $38 \%$ の米タンパ ク質濃樎物を得てこれにリジン，スレオニン補足の実歌 を行なった例と稲垣3) らが米タンパク質レペル $5.6 \%$ ， 10\%，15\%についてリジン補足とリジンとスレオニン補 足の効果について研笔した報告があるにすぎない。

われわれはできるだけ米タンパク質を分画せずにでん 粉を除き米のタンパク質を濃䧽するためプロテアーゼ

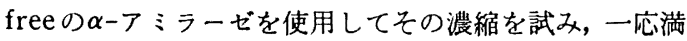
足すべき結果を得たが，今後高価な結晶アミラーゼを使 用せず，たとえ粗アミラーゼでもプロテアーゼ free の 条件で米を処理して実験目的に適合する標品を調製する ことをさらに検討中である。また酵素フミラーゼ処理に よる上清からは飴が得られるばかりでなくタンパク質濃 縮米粉の栄善価がダルテンのそれに比しかなり優れてい る点にかんがみその食用化と，アミノ酸補足による栄症 価の一周の增強などに関しては今後の研究成果によると ころが大である。

これまで米へのスレオニン補足效果の有無と理由に関 し種々論議がなされ，米タンパク質のスレオニンが動物 に利用され難いとする報告などもあっだ)5)。この点に 関しさらに明解な解答を得るため, 飼料中のタンパク質 レベルをかえて小麦ならびに米タンパク質へのリジンや スレオニンの補足効果に関し実験を続行中であるので次 報では米と小麦タンパク質の栄着沜と共にリジン，スレ オニンの補足効果の問題にふれたい。

\section{要旨}

米タンパク質と小麦タンパク質の栄養価を白ネズミの 飼育実鈳によって比較するに当り，両食品につき低タン パク質レペル（米タンパク質レペル），中程度タンパク 質レペル（小麦タンパク質レペル）と高タンパク質レベ ルの飼料を調製するため, 白米を細菌 $\alpha$ ーアミラーゼ処理 により，でん粉の 1 部を除いて，タンパク質濃縮米粉 （倲結乾燥粉末タンパク質 26.9 ～33.9\%）を用意し，小 麦グルテン（タンパク質69.4\%）と小麦でん粉, 米, 小 麦粉などを配合して，各タンパク質レペルの飼料を調製 し，幼白ネズミを20日間自由食で飼育し，タンパク質効 率比 (PER)，生物価(BV) などを求めた。

その結果, 米の PER 1.60 と1. 75 平均 1.67 , 小麦の PER 0.62 と 0.96 平均 $0.79 て ゙, ~ *$ 米の価を 100 とすると 小表では47 (文献値100：79）て，BVは米63.1に対し小 表 49.1 でその Ratio は $100: 78$ (文献值100:89) て いずれす文献にみられるよりも米タンパク質と小麦タン 
パク質の栄養価にかなり大きな開きがあり，米タンパク 質は小麦タンパク質に比し，従来考えられていたより一 垍高い栄養価を有することを認めた。また米，小麦群と も摄取窒素量と体重増加量とはよく相関し, 体重増の傾 斜は米群で体重增量 $10.24 \mathrm{~g} /$ 摂取 $\mathrm{Ng}$, 小麦群で $6.74 \mathrm{~g}$ /Ngでありその比は $100: 66$ であった。

本研究を行な5に当り，資料を御提供下さった大弥食 品, 新進食料工業ならびに上田化学に対し, またタンパ ク質濃縮米などのアミノ酸分析を行なっていただいた田 辺製薬株式会社, 田辺研究所に対し深甚なる感謝の意を 表すると共に，研究費の一部を御援助下さった必須アミ
ノ酸研究委員会に対し，厚く御礼申し上げます。

文献

1) Hegsted, D. M. and Chang, Y. : J. Nutr., 85, 159 (1965)

2 ）中村延生蔵，山田幸二，木村孝雄：栄羡と食粗, 19, 32 (1966)

3 ) 稲垣長典, 蕭舜香, 大西直澄, 津行恵子, 营原す み：栄養と食糧， 16，264（1963）

4) Nonaka, Y. and Ariyama, H. : Agr. Biol. Chem., 26, 635 (1962)

5 ) Nonaka, Y. and Ariyama, H. :Agr. Biol. Chem. 26, 850 (1962)

（昭和 46 年 7 月 8 日受理） 